\title{
Effect of Learning by Utilizing the Jigsaw Technique in Concept Achievement and Motivation to Science for Female Students of the Sixth Grade \\ By \\ Dr. Reem A. Alghamdi
}

\section{Introduction}

In a developed country like Saudi Arabia, where education has taken front seat recently, implementation of teaching strategies is growing at a fast pace to solve the challenges faced by educators to complete the global race (Hamdan, 2005). This transformational phase is evolving from various stages of the traditional ways of learning to cooperative ways of learning or in other word the teaching styles have changed from active teaching to passive teaching, where a shift has been observed from teacher-centered to student-centered focus on learning (Erickson, 2007; Niemi, 2002). This has no doubt many benefits in knowledge acquisition but has also resulted in imposing many challenges on the academic's specialists like Language instructors and administrators to review the existing methods and implement new teaching methods by researching effective methodologies. Hence, the education system has to bear the responsibility of preparing learners in a way that helps them to face the challenges of this age and keep pace with its developments. This cannot be achieved without making a fundamental change in teaching methods that would raise their academic achievement and increase their motivation for the subject and based on what the researcher suggested. Hence, ensuring that there is an increase in the achievement and motivation of the female students of that particular age, updated strategies must be implemented (Prince \& Felder, 2006).

Hence, the education system has to bear the responsibility of preparing learners in a way that helps them to face the challenges of this age and keep pace with its developments (Colby et al., 2003; Senge et al., 2012). This cannot be achieved without making a fundamental change in teaching methods that would raise their academic achievement and increase their motivation for the subject, and based on

* Assistant professor of Science Education - College of Education - Taif University - Kingdom of Saudi Arabia 
what the researcher suggested (Wang \& Holcombe, 2010; Zimmerman \& Schunk, 2012). Ensuring that there is a decrease in the achievement and motivation of the female students of that particular age to science (Denny, 2013).

The world has evolved and is becoming associated with the rapid flow of information. In the current century, where rapid scientific progress in various scientific and technological fields is growing rapidly, gaining new knowledge daily has become mandatory (Ellis \& Goodyear, 2013; Van Laar et al., 2017). So to discover new ways to absorb information easily is a must to survive in this competitive world. That is the main reason why new skills of learning have to be implemented, by focusing on the necessity of life skills. Such as the skill of communication, cooperation, problem-solving, acquiring attitudes, respecting others, and interacting positively with them. This improvement aims to develop the learner in different aspects to adapt to the development that the rapidly changing world demands (Van Laar et al., 2017).

To gain Scientific education is one of the most important aspects of this century, which is characterized by scientific and technological requirements in all areas of life (Van Laar et al., 2017). So, acquiring Scientific education is one of the important means of absorbing the rapid developments of the world today. The world around us has a tremendous amount of technical changes that make our lives evolve in light of developments and requirements. Therefore, schools must adopt new methods of scientific education and prepare individual students to face any new challenges with ease (Noddings, 2015). Education is not just providing information for learners or memorizing and produce the memorized verses, but it is in fact to prepare them to overcome the challenges by researching and gaining the information through participating in the education process (Luna Scott, 2015).

An educational curriculum is the tool of the education system to approach its goals. A lot of experience and skills are needed to deliver the curriculum to learners in the education system (Alismail \& McGuire, 2015) . Or in other words, to achieve the goals of the science curriculum, the educator must have appropriate teaching methods, strategies, and models for the content of the curriculum (Alismail \& McGuire, 2015).

The methods, strategies, and models are used to stimulate an active interaction for learners. Using different ways of teaching will make the students more interesting in the learning, without been bored, 
which is generally observed in traditional teaching (Hugerat, 2016). However, the modern educational model focuses on the students as the center of the learning and education process, unlike the traditional methods' which is teacher-cantered (Zvoch et al., 2019).

The goal of the education system is to get the student to a state of the desired learning. Therefore, it is implying all the possible skills of the curriculum education system (Barnett, 2000). The challenges faced by the education system obligate us to use new technical ways of teaching and learning (Papadakis \& Kalogiannakis, 2017). Collaborative learning is helping the learner to face real-life education problems and to care about individual differences (Chen et al., 2015). Jigsaw is another way of the collaborative learning strategies that actively engage students in two types of groups (Basic \& Expert). Jigsaw is one of the most widespread collaborative learning strategies. It is important in assisting students in participating in-class activities. Also, it helps the teacher to control the classroom and creating a good learning environment (Tekbiyik, 2015).

The scientific concept of Jigsaw is a cooperative strategy that enables each student or group of students to learn or specialize in one aspect of a topic the learner creates from the objects or events available in the surrounded environment (Tekbiyik, 2015). Also, the scientific concept is a group of terms, which used by teachers or researchers as titles. There are three conditions for concepts: Etiquette, Attributes, and Examples. If one of these conditions is missed, the concepts will be misunderstood (Coll \& Coll, 2019; Rugelj, 2015).

Motivation is an important factor in the education system. Motivating the students makes them accept the cognitive activity and it is also is an effective tool to achieve the goals (Cleary \& Zimmerman, 2004). Moreover, motivation is an important factor that interacts with the student's abilities to affect the performance behavior shown by the student in the classroom. It represents the force that moves and excites the student to perform the school work and encourages their enthusiasm or desire to undertake the task of the lesson. This is again reflected in the output intensity of the student's effort (Halawah, 2011).

\section{Problem Statement}

School education in Saudi Arabia is divided into three sections: primary, middle, and high school. High school is the most important part of education because it is the transition phase between school education and University (specialized education like medical or 
engineering in university) (Khoshaim, 2017). However, this transition phase makes learning more meaningful and productive. This research will discuss the impact of the improvement concept and motivation by using the Jigsaw strategy for female students of grade 6 in primary school. Sixth grade is the most senior grade in a primary school in Saudi Arabia, and it prepares the students to step into middle school. Understanding the impacts of Jigsaw strategy, as one of the collaborative learning skills, the concept and motivation of students in the Sixth level is the goal of this research.

\section{Objectives}

- The academic concept of science education for grade six girls' students.

- The motivation of science education for grade six girls' students.

\section{Hypotheses}

The objective of the research is verified by validating the following two null hypotheses:

- There is a statistically significant difference at the level of significance $(0.05)$ between the average scores of the experimental group students who study according to the Jigsaw strategy and the average scores of the control group students who study according to the usual student method concept test.

- There is a statistically significant difference at the level of significance $(0.05)$ between the average scores of the experimental group who study according to the Jigsaw strategy and the average scores of the control group students who study according to the usual method of motivation towards science.

\section{Limits}

- Research is done at primary schools for girls in Taif in Saudi Arabia.

- The research was done on students of the sixth grade in primary schools.

- The research was done on the topics of the third chapter of the science book for the sixth grade in primary schools

- The research was done in primary schools in the second semester of the academic year 2019-2020. 


\section{Literature review}

Collaborative learning is a teaching methodology, where the students, perform their learning tasks with each other through discussions and their understanding of the particular skill and skills information (Häkkinen et al., 2017). The educator needs to plan, implement, make decisions, write procedures, and evaluate to achieve its goals and increase the opportunities for interaction between students and increase their chances of learning different skills, leading to the upgrading of their performance (Retnawati et al., 2018).

\section{Jigsaw strategy}

Generally, Jigsaw means a method of assembling parts or groups. This strategy is called Jigsaw because it is similar to Jigsaw game composition (Azmin, 2016). This method was developed and tested by Elliot Aronson and his team working at Austin schools, Texas in the 1970s (Dabell, 2019). Later, the Jigsaw strategy used by Slavin and his team to develop the relationship between students from different ethnicities (Dabell, 2019; Slavin, 1982). The results showed better results for all students from different ethnic more than before practicing the Jigsaw strategy. Jigsaw's strategy gives positive results in concept achievement and motivation. This method is designed to encourage children to cooperate and work together. Also, it helps to break down personal barriers (Azmin, 2016; Dabell, 2019; Slavin, 1982).

Jigsaw strategy makes the students in small groups. The group members have different interests and abilities. Each member provides a part of the solutions to the mission given to the group. It is not allowed for any member to give a full contribution to solve the purpose, because the goal of the Jigsaw strategy is to reach the solution of the problem through participation and exchange of views. Finally, all group members participate in individual tests covering all elements of the subject (Doymus et al., 2010).

In detail, Jigsaw strategy focuses on student activity in two frameworks: the main group and the specialization group (experts). The classroom is divided into groups (main group). Each group contains 5 to 6 students. Each student of the group has a special task of a general subject. The strategy begins by distributing the same tasks to all of the main teams (five or six tasks in each group). Moreover, depending on the special task, the students gather in the specialization 
groups looking for the task assigned to each of them. In the specialization group, the task is discussed to be solved. Then, each student returns from the specialization group to his or her main group. In the main group, each student, specialized in a particular task, conveys to other members of his team the information reached in the specialization group. Each student plays the role of the teacher and teaches his team about the task of his specialization. That means the task assigned to him did not be limited to learning only to her and himself. However, he or she must teach other members of the main group. This requires a greater effort to master the task. Most important, every student in the main group must learn all aspects of the lesson identified by the teacher. Within the group, there is discussion and questions to ensure that each individual has become understand in all aspects. After that, all groups presenting the results of the work by discussing the subject. Each team displays one task, participating members of the other teams completing it by adding notes and comments, caused by getting the full picture of the subject. Later, the teacher will give a test to all students in a specific task. The students' marks taken in the test are their personal marks and not the group marks (Dabell, 2019; Doymus et al., 2010).

There are numerous benefits of using the Jigsaw strategy in the classroom. It not only helps by implementing positive changes in the performance and ethics of learners, but it also works to build an environment of understanding, respect, and love among the learners (Tomlinson et al., 2008). Moreover, it helps learners to create an appropriate environment in the classroom which contributes to the development of learners' personal skills (Conklin, 2013). Furthermore, it linear the learners on their own aptitude and skill in classroom management, thus builds positive attitudes towards the school, the teacher, and the subject by building good and effective relationships between different groups of learners (Gay, 2006). Finally, an increase in students' educational achievement is achieved by promoting the spirit of teamwork and cooperation among learners (Alfares, 2017).

\section{Improvement academic concept}

Academic achievement is one of the most complex educational concepts. It has many different factors including school environment, personal, social, and economic. In addition, it is one of the most important areas that provide an opportunity to discover students' abilities and develop their talents and aspirations. Therefore, educational institutions are interested in academic achievement, 
because it is an indicator of the extent of its progress towards achieving educational goals, and it's quality (Khalaila, 2015; Lázaro-Visa et al., 2019; Schütte \& Köller, 2015).

Improvement in the student concept has positively influenced academic achievement and other desirable educational outcomes (Marsh \& Martin, 2011). Moreover, Academic concept is an "evaluative self-perception that is formed through the student's experience and interpretation of the school environment" (Guay et al., 2010 , p. 644). The relation between academic concept and academic achievement is a critical issue. According to the self-enhancement model, self-concept is an effect of academic achievement. On the other hand, skill development model proposes that academic self-concept is impacted by academic achievement (Guay et al., 2010). Moreover, Student academic concept affected by many things such as education environment, class members, subjects and teachers (Komarraju et al., 2010).

\section{Motivation}

Motivation is the precursor behind the behavior of humans. There are many reasons for each behavior (Schütte \& Köller, 2015). These reasons are related to the state of the human mind interactions (O'Doherty, 2015). When the personality behavior triggers the external environment, on the other an individual can perform their best when the situation can be handled properly by understanding the nervous system (Rothe, 2017). Scientific research has discovered that internal mental state, such as his needs and inclinations are responsible for the best productive skills of a student or any person (Samokhin et al., 2018). Student motivation could be the key to improving student in science (Buckley \& Doyle, 2016). Student motivation could be internally (intrinsic) or externally (extrinsic) (Buckley \& Doyle, 2016). Intrinsic motivation is enjoying an activity or sees it as an opportunity to explore, learn, and actualize our potentials (Deci \& Ryan, 2010; Reiss, 2012). On the other hand, extrinsic motivation is behaving to earn a reward or avoid punishment (Reiss, 2012).

\section{Methodology}

At the research, an experimental approach is a method used to test the imposition and the relationship between the two variables (dependent and independent). The study also demonstrates the state of studying and caring about the opposite groups, experimental treatment, 
and the standard. As the aim of the research is to identify the impact of teaching Jigsaw strategy, as an independent variable and hence to gain the science concept of students as a dependent variable as well as motivation are important factors. The researcher has adopted the experimental design with partial control with two equal groups, experimental study according to the Jigsaw strategy, and a lesson is taught according to the traditional teaching method.

The current research study group consists of the sixth-grade primary school of female students in Taif for the academic year 2019 - 2020. The researcher took two divisions of 30 students in the sixth grade to represent the experimental group, 30. In addition, a division representing the control group, which is $\mathbf{3 0}$ female students, totaling the number of research students to 60 . To recheck the equality of the groups, the researcher took into consideration the age of student, Intelligence Quotient (IQ) test, previous results, test previous information, and test the earlier motive scale.

The scientific material to be studied had been selected from the science course book, it was the third chapter of grade 6. The third chapter was about the processes of life in plants and microorganisms. Referring to the content of the classes to be conducted, teaching plans for the experimental research groups and the officer were prepared at two classes per week. It implemented in a manner consistent with the independent and dependent variables (Jigsaws in concepts and motivation respectively) for the experimental group and using the usual method for the control group.

\section{Result}

This research discusses two variables, which is the concept of achievement and motivation. This part of the research is going to discuss the results of the data. The data of the experiment done at three stages, before, during, and after the experiment.

Results of students' concept achievement

Average concept achievement of experimental groups, students who studied according to Jigsaw's strategy, before the experiment was (3.5) with a standard deviation of (2.22). While the average achievement of students of the control group, students who studied in traditional learning, was (2.8) with a standard deviation of (2.65), the calculated $T$ value was (1.69), and when compared to the tabular $T$ value at the indication level (0.05) A degree of freedom (58) of (2.00). The square equation (ETA) used to extract the effect size (D) of the independent 
variable in the child dependent variable. The $D$ value of the groups before the experiment was $(0.02)$.

The average concept achievement of experimental groups during the experiment was (11.68) with a standard deviation of (2.83). While the average achievement of students of the control group was (8.86) with a standard deviation of (3.68), the calculated $T$ value was (6.04) comparing to the tabular $T$ value at the indication level $(0.05) A$ degree of freedom (58) of (2.00). The $D$ value of the groups during the experiment was $(0.16)$.

The average concept achievement of experimental groups after a week of the experiment was (12.59) with a standard deviation of (0.79). While the average achievement of students of the control group was (9.77) with a standard deviation of (3.11), the calculated $T$ value was (7.80) comparing to the tabular $T$ value at the indication level (0.05) $A$ degree of freedom (58) of (2.00). The $D$ value of the groups during the experiment was $(0.28)$.

\section{Motivation Results}

The average motivation of experimental groups before the experiment was (47.18) with a standard deviation of (8.93). While the average motivation of students of the control group was (46.33) with a standard deviation of (7.7), the calculated $T$ value was (1.18), and when compared to the tabular $T$ value at the indication level (0.05) $A$ degree of freedom (58) of (2.00). The square equation (ETA) used to extract the effect size (D) of the independent variable in the child dependent variable. The $D$ value of the groups before the experiment was (0.1).

The average motivation of experimental groups during the experiment was (49.3) with a standard deviation of (8.4). While the average motivation of students of the control group was (46.5) with a standard deviation of (8.1), the calculated $T$ value was (3.77), and when compared to the tabular $T$ value at the indication level $(0.05) A$ degree of freedom (58) of (2.00). The square equation (ETA) used to extract the effect size (D) of the independent variable in the child dependent variable. The $D$ value of the groups before the experiment was $(0.34)$.

The average of motivation experimental groups after the experiment was (49.6) with a standard deviation of (7.5). While the average motivation of students of the control group was (46.2) with a standard deviation of (8.1), the calculated $T$ value was (4.72), and when compared to the tabular $T$ value at the indication level $(0.05) A$ degree of freedom (58) of (2.00). The square equation (ETA) used to extract the 
effect size (D) of the independent variable in the child dependent variable. The $D$ value of the groups before the experiment was $(0.43)$.

\section{Discussion}

It has been proved from the results that the group learned by the Jigsaw learning method has more achievement and motivation than the group learned in the traditional way. There are many reasons to make this difference. The reasons are related to students, teachers, learning environments and learning way.

Firstly, cooperative learning, like a jigsaw, increases the interaction between students and increases their chances of learning different skills, at the same time which leads to raising their level of performance. Sometimes, students need to compete with others to increase their ability. In the jigsaw strategy, the learning is depended on the students. Each student would like to show the best he/she ability. This competition shows the best of the students through confrontation with others. On the other hand, teachers need not need to inform everything, and students exchange the information learn from each other. They can ask any question and make open discussion without hesitation. For these reasons, students would like the classroom and motivate them to learn science. Moreover, it develops the spirit of work and university cooperation among them, also contributes to developing their personal skills and building positive attitudes towards the school, the teacher, the academic subject and the teachers simultaneously.

Secondly, during cooperative learning, the science teacher focuses on controlling the classroom and encouraging science learning rather than focusing deliver the science information. The results show that the group was learning by Jigsaw's strategy had more science concept achievement and more motivation, which means that teachers focus on the quality of science learning rather than trying to deliver the lesson.

Finally, cooperative learning makes the learning environment more attractive because it is avoiding the passivity of traditional learning. It makes the students control the lesson while the teacher focuses on the learning quality. Enhancing the students to be active leads to rising motivation, which leads to an increase in concept achievement. 


\section{Conclusion and recommendation}

This study has discussed the influence of cooperative learning, such as the Jigsaw strategy, on the students, who were studying science in Sixth grade. We found that the students who learn through the Jigsaw strategy have more concept achievement and motivation to science.

Referring to the result, we recommend utilizing the teaching strategy of Jigsaw in teaching science through diversification in the use of teaching methods, training science teachers on applying the Jigsaw cooperative teaching strategy in training instead of the particular process, conducting studies similar to this one, address other variables, increasing the number of research and studies on the impact of using the Jigsaw cooperative learning strategy on achievement in subjects other than science and study levels different from the sixth grade. 


\section{References}

Alfares, N. (2017). Benefits and Difficulties of Learning in Group Work in EFL Classes in Saudi Arabia. English Language Teaching, 10(7), 247-256.

Alismail, H. A., \& McGuire, P. (2015). 21st century standards and curriculum: Current research and practice. Journal of Education and Practice, 6(6), 150-154.

Azmin, N. H. (2016). Effect of the Jigsaw-Based Cooperative Learning Method on Student Performance in the General Certificate of Education Advanced-Level Psychology: An Exploratory Brunei Case Study. International Education Studies, 9(1), 91-106.

Barnett, R. (2000). Supercomplexity and the curriculum. Studies in higher education, 25(3), 255-265.

Buckley, P., \& Doyle, E. (2016). Gamification and student motivation. Interactive Learning Environments, 24(6), 1162-1175. doi:10.1080/10494820.2014.964263

Chen, C.-H., Wang, K.-C., \& Lin, Y.-H. (2015). The comparison of solitary and collaborative modes of game-based learning on students' science learning and motivation. Journal of Educational Technology \& Society, 18(2), 237-248.

Cleary, T. J., \& Zimmerman, B. J. (2004). Self-regulation empowerment program: A school-based program to enhance self-regulated and self-motivated cycles of student learning. Psychology in the Schools, 41(5), 537-550.

Colby, A., Beaumont, E., Ehrlich, T., \& Stephens, J. (2003). Educating citizens: Preparing America's undergraduates for lives of moral and civic responsibility (Vol. 6): John Wiley \& Sons.

Coll, S. D., \& Coll, R. K. (2019). Enhancing Science Learning Through Learning Experiences Outside School (LEOS): How to Learn Better During Visits to Museums, Science Centers, and Science Fieldtrips: BRILL.

Conklin, T. A. (2013). Making it personal: The importance of student experience in creating autonomy-supportive classrooms for millennial learners. Journal of Management Education, 37(4), 499-538.

Dabell, J. (2019). What is the jigsaw classroom technique? Seced, 2019(11), 14-15.

Deci, E. L., \& Ryan, R. M. (2010). Intrinsic motivation. The corsini encyclopedia of psychology, 1-2. 
Denny, P. (2013). The effect of virtual achievements on student engagement. Paper presented at the Proceedings of the SIGCHI conference on human factors in computing systems.

Doymus, K., Karacop, A., \& Simsek, U. (2010). Effects of jigsaw and animation techniques on students' understanding of concepts and subjects in electrochemistry. Educational technology research and development, 58(6), 671-691.

Ellis, R., \& Goodyear, P. (2013). Students' experiences of e-learning in higher education: the ecology of sustainable innovation: Routledge.

Erickson, D. M. (2007). A developmental re-forming of the phases of meaning in transformational learning. Adult education quarterly, $58(1), 61-80$.

Gay, G. (2006). Connections between classroom management and culturally responsive teaching. Handbook of classroom management: Research, practice, and contemporary issues, 343370.

Häkkinen, P., Järvelä, S., Mäkitalo-Siegl, K., Ahonen, A., Näykki, P., \& Valtonen, T. (2017). Preparing teacher-students for twenty-firstcentury learning practices (PREP 21): a framework for enhancing collaborative problem-solving and strategic learning skills. Teachers and Teaching, 23(1), 25-41.

Halawah, I. (2011). FACTORS INFLUENCING COLLEGE STUDENTS'MOTIVATION TO LEARN FROM STUDENTS'PERSPECTIVE. Education, 132(2).

Hamdan, A. (2005). Women and education in Saudi Arabia: Challenges and achievements. International Education Journal, 6(1), 42-64.

Hugerat, M. (2016). How teaching science using project-based learning strategies affects the classroom learning environment. Learning Environments Research, 19(3), 383-395.

Khalaila, R. (2015). The relationship between academic self-concept, intrinsic motivation, test anxiety, and academic achievement among nursing students: Mediating and moderating effects. Nurse Education Today, 35(3), 432-438.

Khoshaim, H. B. (2017). High School Graduates' Readiness for Tertiary Education in Saudi Arabia. International Journal of Instruction, 10(3), 179-194.

Lázaro-Visa, S., Palomera, R., Briones, E., Fernández-Fuertes, A., \& Fernández-Rouco, N. (2019). Bullied adolescent's life 
satisfaction: personal competencies and school climate as protective factors. Frontiers in psychology, 10, 1691.

Luna Scott, C. (2015). The Futures of Learning 3: What kind of pedagogies for the 21 st century?

Niemi, H. (2002). Active learning-a cultural change needed in teacher education and schools. Teaching and teacher education, 18(7), 763-780.

Noddings, N. (2015). The challenge to care in schools, 2nd Editon: Teachers College Press.

O'Doherty, J. P. (2015). Multiple systems for the motivational control of behavior and associated neural substrates in humans Behavioral Neuroscience of Motivation (pp. 291-312): Springer.

Papadakis, S., \& Kalogiannakis, M. (2017). Mobile educational applications for children: what educators and parents need to know. International Journal of Mobile Learning and Organisation, 11(3), 256-277.

Prince, M. J., \& Felder, R. M. (2006). Inductive teaching and learning methods: Definitions, comparisons, and research bases. Journal of engineering education, 95(2), 123-138.

Reiss, S. (2012). Intrinsic and extrinsic motivation. Teaching of Psychology, 39(2), 152-156.

Retnawati, H., Djidu, H., Kartianom, A., \& Anazifa, R. D. (2018). Teachers' knowledge about higher-order thinking skills and its learning strategy. Problems of Education in the 21st Century, $76(2), 215$.

Rothe, J. P. (2017). The scientific analysis of personality: Routledge.

Rugelj, J. (2015). Serious computer games in computer science education. EAI Endorsed Trans. Serious Games, 2(6), e6.

Samokhin, I. S., Sergeeva, M. G., Tabuyeva, E. V., Stanchulyak, T. G., \& Kolesina, E. G. (2018). Assessment of student's potential based on the data concerning productivity and psychological comfort of education. Espacios, 39(2), 22.

Schütte, K., \& Köller, O. (2015). 'Discover, Understand, Implement, and Transfer': Effectiveness of an intervention programme to motivate students for science. International journal of science education, 37(14), 2306-2325.

Senge, P. M., Cambron-McCabe, N., Lucas, T., Smith, B., \& Dutton, J. (2012). Schools that learn (updated and revised): A fifth discipline fieldbook for educators, parents, and everyone who cares about education: Currency. 
Slavin, R. E. (1982). Cooperative learning: Student teams. What research says to the teacher: ERIC.

Tekbiyik, A. (2015). The use of jigsaw collaborative learning method in teaching socio-scientific issues: The case of nuclear energy. Journal of Baltic Science Education, 14(2), 237.

Tomlinson, C. A., Brimijoin, K., \& Narvaez, L. (2008). The differentiated school: Making revolutionary changes in teaching and learning: ASCD.

Van Laar, E., Van Deursen, A. J., Van Dijk, J. A., \& De Haan, J. (2017). The relation between 21 st-century skills and digital skills: A systematic literature review. Computers in human behavior, 72, 577-588.

Wang, M.-T., \& Holcombe, R. (2010). Adolescents' perceptions of school environment, engagement, and academic achievement in middle school. American educational research journal, 47(3), 633662.

Zimmerman, B. J., \& Schunk, D. H. (2012). Self-regulated learning and academic achievement: Theory, research, and practice: Springer Science \& Business Media.

Zvoch, K., Holveck, S., \& Porter, L. (2019). Teaching for Conceptual Change in a Density Unit Provided to Seventh Graders: A Comparison of Teacher- and Student-Centered Approaches. Research in Science Education. doi:10.1007/s11165-019-09907-8 


\begin{abstract}
This research aimed to prove the scientific effects of using the Jigsaw strategy by demonstrating its results, in order to motivate the educational institutes to implement jigsaw skills is the goal of this educational research. In this research, the difference between cooperative learning, like the Jigsaw strategy, and traditional learning way are compared. This research was performed on a total of 60 female students of grade 6 primary school in Al Taif city of Saudi Arabia. At the end of the experiment, it has been found that the consequences in concepts achievement and the motivation were statistically higher or rewarding while utilizing the Jigsaw strategy.

Keywords; Jigsaw Strategy, Cooperative Learning, Teaching Methodology, Motivation, Concept Achievement
\end{abstract}


Effect of Learning by Utilizing the Jigsaw ------- Dr/ Reem A. Alghamdi أثر استخدام استراتيجية جيسكو في تنمية المفاهيم وزيادة التحفيز نحو مادة العلوم لاى طالبات الصف السادس الابتدائي

هاف البحث إلى التعرف على أثر استخام استراتيجية جيسكو في العملية التعليمية من خلال

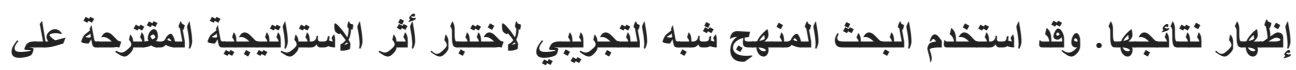

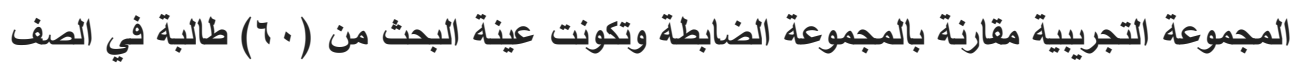

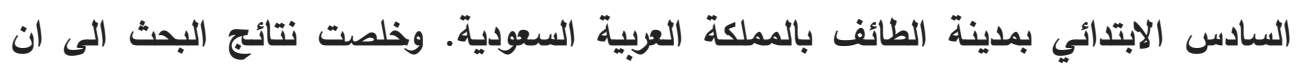

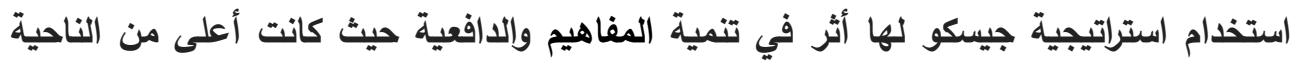
الإحصائية أثناء استخدام استراتيجية جيكسو. 